\title{
1 A VIDA NA FAZENDA: SENTIDOS \\ SUBJETIVOS DO SERVIDOR FAZENDÁRIO ANTE A PARTICIPAÇÃO NO TRABALHO
}

\section{ROGÉRIO ZANON DA SILVEIRA}

Doutorando em Administração pelo Centro de Pós-Graduação em Administração da

Universidade Federal de Minas Gerais (UFMG).

Mestre em Administração pela Universidade Federal do Espírito Santo (Ufes).

Auditor fiscal da Receita Estadual da Secretaria de Estado da Fazenda do Espírito Santo (Sefaz). Avenida Antônio Carlos, 6.627, Face/Cepead, sala 4012, Pampulha, Belo Horizonte - MG - Brasil - CEP $31270-901$

E-mail: rsilveira@sefaz.es.gov.br

\section{MÁRCIA PREZOTTI PALASSI}

Doutora em Psicologia Social pela Faculdade de Psicologia da

Pontifícia Universidade Católica de São Paulo (PUC-SP).

Professora do Programa de Pós-Graduação em Administração e em Ciências Sociais da Universidade Federal do Espírito Santo (Ufes). Avenida Fernando Ferrari, 514, campus universitário, Goiabeiras, Vitória - ES - Brasil - CEP 29075-910

E-mail: mprezotti@hotmail.com

É permitido copiar, distribuir, exibir e transmitir essa obra; bem como criar obras derivadas, desde que se confira o devido crédito autoral e se referencie a publicação anterior na RAM (nome da revista, edição, ano e páginas) de forma explícita e clara (mas sem sugerir que a RAM apoia ou endossa o usuário ou o uso feito da obra). Por meio dessa licença, fica explicito a restrição ao uso da obra para fins comerciais. No caso de alteração, transformação ou adaptação dessa obra, você deve distribuir a obra resultante somente nas mesmas condições de licenciamento aqui estabelecidas. 


\section{RESUMO}

O problema de pesquisa deste estudo tem origem em inquietações dos autores, ao longo de mais de vinte anos de serviço público, sobre a diversidade e a complexidade da participação no trabalho, nem sempre explicável objetivamente: que sentidos subjetivos perpassam o servidor público fazendário no que tange à participação no trabalho? Este artigo visa compreender os sentidos subjetivos do servidor fazendário ante a participação no trabalho. O referencial teórico é a teoria da subjetividade na perspectiva histórico-cultural de González Rey (2003, 2005), que propõe uma concepção de subjetividade baseada numa compreensão histórico-cultural do homem, rompendo com a dicotomia entre o social e o individual. A essa perspectiva da subjetividade são associados estudos de autores (inter)nacionais sobre a participação no trabalho, como O'Donoghue, Stanton e Bartram (20II), Zani e Spinelli (20I0), Neves e Castro (20I0), Palgi (2006), Cox, Zagelmeyer e Marchington (2006), Demo (I988), Coutinho (2006) e Leal Filho (2009). Adota-se um conceito de participação associado às formas e aos meios pelos quais os trabalhadores e dirigentes de uma organização influenciam seus destinos (MOTTA, I999). Trata-se de um estudo de natureza qualitativa baseada na epistemologia qualitativa (GONZÁLEZ REY, 2005). As interpretações fundamentam-se na acepção de sentido subjetivo (GONZÁLEZ REY, 2003, 2005). Os sujeitos pesquisados são sete auditores fiscais da Secretaria de Estado da Fazenda do Espírito Santo (Sefaz). O levantamento dos dados deu-se em quatro momentos empíricos, entre julho de 2009 e fevereiro de 20 Io. As interpretações evidenciam sentidos subjetivos relevantes em cada um dos sujeitos ante a participação no trabalho, associados, entre outros: à visão ideológica, ao núcleo familiar, à autoestima, ao novo e à mudança, à formalidade e à família. Os resultados possibilitam também identificar elementos marcantes da subjetividade social prevalente na instituição, destacando-se: cultura baseada no controle, mistura entre relações de amizade e profissionais, e carência de espaços de participação. Por fim, sugerem-se medidas no sentido de aprimorar a relação servidor-instituição e a participação do servidor no trabalho, e são abordadas lacunas, limitações do estudo e questões para pesquisas futuras. 


\section{PALAVRAS-CHAVE}

Participação no trabalho; Subjetividade; Sentidos subjetivos; Auditor fiscal; Administração Pública.

\section{"ACHO QUE ÉRAMOS MUITO JOVENS": INTRODUÇ ÃO}

Este artigo se insere no tema da participação no trabalho na Administração Pública, cujo conceito de participação refere-se às formas e aos meios pelos quais os trabalhadores e dirigentes de uma organização influenciam seus destinos (MOTTA, I999). Agrega-se ao conceito a busca deliberada e consciente do trabalhador em participar do desenvolvimento da organização ou instituição da qual faz parte, desde os níveis operacionais aos estratégicos, à busca pelo alcance dos resultados planejados e por sua distribuição. Não se pode falar ainda da existência de uma teoria de participação no trabalho, mas existem muitos estudos que tratam do tema. Especificamente sobre a participação no trabalho na Administração Pública, no entanto, os estudos são raros, como comprovou a pesquisa realizada por Silveira e Palassi (2009), por exemplo. Por isso, e em consonância com o escopo do artigo, foram escolhidos trabalhos relevantes e com abordagens diferenciadas, com o objetivo de apresentar ao leitor conteúdo suficiente para entendimento do assunto.

A relação entre subjetividade e participação no trabalho pode ser visualizada na teoria da subjetividade de González Rey (2003), pois o autor menciona que a categoria de sujeito implica necessariamente a de participação, uma vez que o sujeito situa-se numa região de prática social. Numa dimensão maior, a da esfera política, a participação é considerada a base da democracia, que Sen (I999) acredita se consolidar cada vez mais como um estado de participação. Mendonça (I987) enfatiza que, na teoria democrática, a participação não se restringe à participação política, alcançando organizações e instituições, como extensão da democracia política existente na sociedade civil. Além dos benefícios que pode acarretar para trabalhadores e organizações, a participação no trabalho deve ser vista como valor intrínseco à democracia, especialmente no âmbito da Administração Pública.

No Brasil, todos os sujeitos que servem ao Poder Público são chamados de agentes públicos, que se classificam em agentes políticos e servidores estatais. Em sentido amplo, os servidores públicos são as pessoas físicas que prestam 
serviços ao Estado e às entidades da Administração Indireta e para isso possuem vínculo empregatício. Compreendem os servidores estatutários, os empregados públicos e os servidores temporários, e são remunerados pelos cofres públicos (MELLO, 2000).

O problema de pesquisa nasce das inquietações dos autores deste artigo, amadurecidas ao longo de uma carreira de mais de vinte anos no serviço público, período em que foram observando e problematizando a participação no trabalho. Verifica-se que, em momentos diferentes, a participação no trabalho varia muito de um indivíduo para o outro, com durações diferentes em cada um e em diferentes níveis e intervalo, e tentativas de explicação para essas situações são quase sempre vãs. Os fatores objetivos, por si sós, não são suficientes para compreender a diversidade e a complexidade da participação no trabalho, e daí emerge o problema de pesquisa: que sentidos subjetivos perpassam o servidor público fazendário no que tange à participação no trabalho? O objeto de estudo refere-se aos sentidos subjetivos do servidor fazendário, e o objetivo deste artigo é compreender os sentidos subjetivos do servidor fazendário ante a participação no trabalho. Trata-se de uma pesquisa de natureza qualitativa, pautada na teoria da subjetividade e na epistemologia e metodologia qualitativa de González Rey (2003, 2005), cujo método de pesquisa é o estudo de caso (GONZÁLEZ REY, I999). Os sujeitos pesquisados são sete auditores fiscais da Secretaria de Estado da Fazenda do Espírito Santo (Sefaz), com vínculo empregatício estatutário, e a delimitação do estudo é a Subsecretaria de Estado da Receita (Subser).

A relevância do estudo reside na compreensão da participação no trabalho, servindo de subsídio ao desenvolvimento de planos, diretrizes e ações voltados à melhoria da efetividade da instituição, o que, para a sociedade, significa mais qualidade nos processos de captação e alocação de recursos públicos. Para a área acadêmica, o estudo contribui ao preencher uma lacuna nos estudos sobre participação no trabalho na Administração Pública. Em mapeamento realizado por Silveira e Palassi (2009), constata-se a ênfase no estudo da participação popular na Administração Pública, mas a falta de estudos sobre a participação do servidor público no cotidiano do seu trabalho é comprovada.

Este artigo está estruturado em sete partes, sendo a primeira esta introdução. A segunda apresenta a teoria da subjetividade sob o enfoque histórico-cultural de González Rey (2003) e conceitos e estudos sobre participação no trabalho, buscando integrar os dois assuntos. A terceira parte descreve a epistemologia qualitativa de González Rey (2005). A quarta parte contextualiza histórica e culturalmente a Sefaz. A quinta parte é a interpretação dos momentos empíricos, e a sexta apresenta os sentidos subjetivos relevantes nos sujeitos de pesquisa. $\mathrm{Na}$ sétima e última parte, são tecidas as considerações finais. 


\section{"AQUILO ME FEZ PENSAR": REFERENCIAL TEÓRICO}

O referencial teórico deste trabalho é a teoria da subjetividade na perspectiva histórico-cultural de González Rey (2003). O autor parte da proposição de que o homem é constituído a partir de sua reflexibilidade durante sua história, processo no qual seu pensamento atua por meio de situações que provoquem sua emoção. O exercício do pensamento vai além da linguagem. Entre os indivíduos, há uma relação complementar e contraditória, "em que um não se reduz ao outro, e nem é explicado pelo outro" (GONZÁLEZ REY, 2003, p. 235). Por meio de seu processo reflexivo, o sujeito voluntária ou deliberadamente intervém na produção de sua própria subjetividade e na constituição subjetiva dos espaços sociais em que atua, de onde intervém também em outros espaços sociais. Nesse sujeito, a linguagem não aparece de forma isolada, produzida apenas a partir da cognição. A linguagem surge no indivíduo repleta de sentidos subjetivos, traduzindo emoções complexas do sujeito e gerando novas emoções, em seu constante trânsito nos diferentes espaços sociais: "A emoção é uma condição permanente na definição do sujeito. A linguagem e o pensamento se expressam a partir do estado emocional de quem fala e pensa" (GONZÁLEZ REY, 2003, p. 236).

Nessa acepção de sujeito, como sujeito de pensamento, emoção e linguagem, é que emerge o sujeito reflexivo e participativo de González Rey (2003, p. 240): "A reflexibilidade é uma característica do sujeito com a qual está comprometida a produção de sentidos subjetivos em todas as esferas da vida”. Por meio do pensamento e de novas práticas sociais, o sujeito encara permanentemente suas posições anteriores e enfrenta momentos em que rompe com o social, resultando no surgimento de novos focos de subjetivação social. O enfoque histórico-cultural rompe com a visão que constringe a subjetividade ao intrapsíquico e "se orienta para uma apresentação da subjetividade que em todo o momento se manifesta na dialética entre o momento social e o individual", em que o momento individual está representado por um sujeito comprometido permanentemente "no processo de suas práticas sociais, de suas reflexões e de seus sentidos subjetivos" (GONZÁLEZ REY, 2003, p. 240).

\section{"Aí O CORAÇÃO APERTOU": A SUBJETIVIDADE NA PERSPECTIVA HISTÓRICO-CULTURAL}

González Rey (2003, p. 9) defende um conceito de subjetividade que não guarda relação com o conceito desenvolvido em algumas correntes filosóficas da modernidade: 
A subjetividade [...] é um complexo e plurideterminado sistema, afetado pelo próprio curso da sociedade e das pessoas que a constituem dentro do contínuo movimento das complexas redes de relações que caracterizam o desenvolvimento social. Essa visão da subjetividade está apoiada com particular força no conceito de sentido subjetivo, que representa a forma essencial dos processos de subjetivação.

González Rey (2005) propõe uma concepção de subjetividade pautada numa compreensão histórico-cultural do homem. Nessa concepção, os sentidos subjetivos procedentes das experiências atuais e anteriores do sujeito constituem subjetivamente sua manifestação em cada espaço social concreto. Assim, o estudo do sujeito em cenários microssociais implica compreender os comportamentos ali produzidos por meio dos sentidos subjetivos desse comportamento (GONZÁLEZ REY, 2003). Sentido subjetivo é definido como

[...] a unidade inseparável dos processos simbólicos e as emoções num mesmo sistema, no qual a presença de um desses elementos evoca o outro, sem que seja absorvido pelo outro. [...] O sentido subjetivo representa uma definição ontológica diferente para a compreensão da psique como produção cultural (GONZÁLEZ REY, 2005, p. 22).

O conceito dá particular sustentação à concepção de subjetividade do autor. A subjetividade é legitimada pelo fato de ser "uma produção de sentidos subjetivos que transcende toda a influência linear e direta de outros sistemas da realidade" (GONZÁLEZ REY, 2005, p. 22).

González Rey (2003) considera a necessidade de superar a visão mecanicista de ver cultura, sujeito e subjetividade como fenômenos diferentes e passar a vê-los como fenômenos que se integram. Seu conceito de subjetividade é uma tentativa de superar a dicotomia entre o social e o individual, dicotomia que tem influenciado forte e historicamente a construção do pensamento psicológico, em sua opinião. A teoria da subjetividade assumida pelo autor está orientada por uma dialética entre o momento social e o individual, de forma constante nas práticas, nas reflexões e nos sentidos subjetivos da pessoa. O sujeito não é um reflexo do social, mas o resultado de uma confrontação com o social e com sua própria subjetividade. O autor reconhece que, em momentos anteriores de seu próprio trabalho, o sujeito era definido como um "indivíduo consciente, intencional, atual e interativo, condições permanentes para sua expressão vital e social" (GONZÁLEZ REY, 2003, p. 236). Mas, a partir de determinado ponto, encontra um aspecto que considera central, sobre o qual não havia se detido 
antes, que é o de considerar o sujeito como sujeito da emoção: "a emoção é uma condição permanente na definição do sujeito” (GONZÁLEZ REY, 2003, p. 238).

\section{2 "[...] PENSEI NO MEU FILHO, MINHA FAMÍLIA [...]": PARTICIPAÇÃO NO TRABALHO E SUBJETIVIDADE}

González Rey (2003, p. 238) defende que a categoria de sujeito implica necessariamente a de participação, pois ele está situado numa região da prática social: "Portanto, o reconhecimento dessa categoria é um aspecto central no reconhecimento do caráter social da subjetividade individual". O conceito de subjetividade social, além de romper com a dicotomia entre o individual e o social, realça que esses espaços não podem ser vistos de forma fracionada. Ao se inserir nesse complexo sistema de configuração subjetiva, a subjetividade gerada no campo do trabalho influencia e é simultaneamente influenciada pelos diversos espaços que compõem o tecido social, como a família, a religião, os estudos, entre outros. Dessa mesma forma, a subjetividade individual do trabalhador está atravessada de forma permanente pela subjetividade social, que, por sua vez, aparece constituída de forma diferenciada em cada um deles, o que remete à reflexão de que "as sociedades humanas não podem ser explicadas apenas por suas condições objetivas de existência” (GONZÁLEZ REY, 2003, p. I04).

Arendt (I999, p. 3I) lembra que "só a ação é prerrogativa exclusiva do homem; nem um animal nem um deus é capaz de ação e só a ação depende inteiramente da constante presença dos outros”. Assim, pressupõe-se que a noção de que os trabalhadores devem participar no trabalho é antiga, mas ganhou ênfase principalmente nas últimas décadas do século XX. O Direito Administrativo, como ramo autônomo, nasceu em fins do século XVIII, mas, onde quer que tenha existido o Estado, normas administrativas, órgãos e pessoas encarregadas do exercício de funções administrativas existiram. Porém, eram normas esparsas, não elaboradas em princípios que lhes imprimissem uma condição autônoma. $\mathrm{Na}$ Idade Média, o Direito Administrativo encontrou um ambiente muito inóspito para o seu desenvolvimento:

[...] era a época das monarquias absolutas, em que todo poder pertencia ao soberano; a sua vontade era a lei, a que obedeciam todos os cidadãos, justificadamente chamados de servos ou vassalos (aqueles que se submetem à vontade de outrem) (DI PIETRO, 2003, p. 23).

A participação, entretanto, nunca deixou de existir, e com ela as revoluções que acabaram com o velho regime absolutista. É do berço das revoluções que 
nasce o Direito Administrativo, cujo conteúdo varia conforme o tipo de Estado adotado, pois quanto maior a abertura do Estado para a democracia, maior é o seu envolvimento em inúmeras áreas, como a saúde, a educação, a assistência e a previdência sociais, e a cultura (DI PIETRO, 2003). Na esfera política, participação é a base da democracia, nome dado pelos gregos desde a Antiguidade à ideia de participação das pessoas nos processos decisórios. Sen (I999) enfatiza que a democracia se consolida cada vez mais como um estado de participação. $\mathrm{Na}$ teoria democrática, a participação não se restringe à participação política e alcança o âmbito das organizações e instituições, pressupondo a participação nesses espaços como extensão da democracia política na sociedade civil (MENDONÇA, I987).

Em busca realizada pelos autores deste artigo nos principais eventos e periódicos, nacionais e internacionais, especialmente no campo da Administração, foi constatado que é pequena a publicação sobre o tema pesquisado: participação no trabalho na gestão pública. Aqui são apresentados estudos recentes que o tangenciam e ajudam a compreendê-lo. O’Donoghue, Stanton e Bartram (20II), por exemplo, analisam a participação dos empregados em três organizações da área de saúde na cidade de Victoria, na Austrália. Os autores investigaram a participação na prática e fatores que facilitam e dificultam a participação no trabalho. Chegaram à conclusão de que o apoio de dirigentes é precondição para o estabelecimento da participação dos empregados no trabalho. McCrea e Ferguson (20II) pesquisaram o papel da gestão participativa como mediadora entre gestores e empregados, e estenderam a pesquisa ao setor público em Queensland, na Austrália. Zani e Spinelli (20I0) estudaram a implementação de política de gestão pública do Estado do Espírito Santo voltada à participação de servidores públicos em processos e projetos inovadores. Os autores concluem que a participação social limitada não garante o atendimento das demandas reais apresentadas pela sociedade e que a implementação do "Prêmio Inoves", como objetivo principal da inovação, conduz ao risco de que as categorias premiadas transformem-se em veículos únicos a direcionarem inovações. Pereira e Osburn (2007) estudaram os efeitos da participação em diversas atitudes e performances dos empregados. Os resultados mostraram relação positiva entre participação, qualidade da gestão e produtividade.

Neves e Castro (20I0) procuram compreender como se deu o processo de envolvimento e participação dos servidores na implantação da mudança institucional que ficou conhecida como "Choque de Gestão" em Minas Gerais, a partir de 2003 . Os resultados sinalizam que fatores considerados na literatura como essenciais para o envolvimento e a participação dos servidores públicos no processo de mudança, como participação na tomada de decisão, trabalho em 
equipe e comunicação interna, foram utilizados insatisfatória e ineficientemente. Palgi (2006) chama atenção para o florescimento de diversas visões sobre participação nas organizações que surgiram na segunda metade da década de I990, que podem ser divididas em três perspectivas principais: participação nas decisões, participação nos lucros e participação na sociedade. Seu artigo apresenta mudanças teóricas e práticas ocorridas nesses temas nos anos estudados, em termos de estrutura, processo e ideologia. Castro, Pacheco e Patrus-Pena (2009) estudam a relação entre gestão participativa na empresa e relações entre organização e sindicato. Chegam à conclusão de que altos salários na área de serviços podem indicar que a gestão participativa, quando percebida pelos empregados, está acompanhada da percepção de que a relação entre empresa e sindicato é fraca. Ghorpade, Lackritz e Singh (2006) mostram a correlação positiva existente entre as visões de participação dos empregados e altruísmo, orgulho profissional e coletivismo em diferentes grupos de idade. Os autores também discutem as implicações dos resultados para a prática organizacional e para as políticas públicas. Cox, Zagelmeyer e Marchington (2006) associaram o envolvimento da participação dos trabalhadores a altos níveis de comprometimento organizacional e de satisfação no trabalho.

Prestes-Motta (I982, p. I5) foi um dos pensadores brasileiros mais preocupados com o caráter manipulável de diversas perspectivas de participação desenvolvidas no meio empresarial, mas compreendia a participação como "uma conquista e uma arma dos trabalhadores", bem como entendia formas éticas participativas de gestão como avanço no capitalismo. Coutinho (2006) guia-se por questões como se pode ou não o trabalhador ser um parceiro no processo produtivo, e sobre o perfil do trabalhador participante ou parceiro no processo produtivo. Os resultados não indicam homogeneidade nos perfis profissionais, mostrando uma realidade complexa na qual a articulação entre o velho e o novo se apresenta de maneira diferenciada em cada tipo de trabalhador e em cada fábrica. Coutinho (2006, p. 302) interpreta nessa heterogeneidade a natureza ativa e reflexiva do trabalhador:

[...] um sujeito ativo, capaz de resistir às pressões organizacionais. A capacidade de resistir, inventar novas formas de sobrevivência seria, talvez, o traço fundamental de um povo que, como diria o poeta, cotidianamente enfrenta uma vida “Severina”.

Kliksberg (I999) apresenta teses, com base em estudos empíricos, associando participação no âmbito organizacional com benefícios como maior produti- 
vidade, motivação, redução de custos, melhor qualidade dos serviços prestados, inovação, criatividade e redução do absenteísmo e rotatividade de pessoal. Leal Filho (2009) acrescenta que tais organizações atraem pessoal mais qualificado. Motta (I999) desenvolve um conceito amplo ao defender que a participação compreende todas as ações e formas por meio das quais os membros influenciam os destinos de uma organização. McLagan (2000) chama a atenção para o movimento crescente da participação dos trabalhadores no rumo das organizações, movimento favorecido pela disponibilização das informações em meio eletrônico. Quanto maior for a participação e o envolvimento dos membros de uma organização, maior será o comprometimento com o trabalho (LEAL FILHO, 2009). Demo (I988) defende que "Participação é Conquista" e cita que a participação ampla e consciente no âmbito público é fundamental para a burocracia não se voltar para si mesma, tornando-se emperrada e alienada do serviço à comunidade, preocupação compartilhada pelos autores deste trabalho.

\section{"Agíamos com o coração MUITO ABERTO": A PROPOSTA DA "EPISTEMOLOGIA QUALITATIVA"}

Ao tratar de processos complexos que constituem a subjetividade e de elementos que não se mostram evidentes, como os sentidos subjetivos, o estudo naturalmente se orienta para o modelo qualitativo de pesquisa. Neste estudo, a pesquisa qualitativa se baseia na epistemologia qualitativa (GONZÁLEZ REY, 2005), entendida, nas ciências antropossociais, como um processo de comunicação e de diálogo, uma vez que o homem se comunica permanentemente nos diversos espaços sociais em que vive. O método de pesquisa adotado é o estudo de caso (GONZÁLEZ REY, I999), e a construção do conhecimento fundamentase especialmente em três princípios básicos. O primeiro é a defesa do caráter "construtivo-interpretativo do conhecimento", o que implica entender o conhecimento como produção permanente e não como apropriação linear de uma realidade que se nos apresenta. O segundo é a legitimação do singular como fonte de produção do conhecimento, o que implica considerar a pesquisa como uma produção teórica. O terceiro atributo consiste em entender a pesquisa nas ciências antropossociais como um processo de comunicação e de diálogo, rompendo com a neutralidade do investigador, instigando-o a manter uma relação ativa com as pessoas que fazem parte da pesquisa (GONZÁLEZ REY, 2005, p. 5).

A delimitação do estudo é a Subser, órgão integrante da Sefaz. Os sujeitos de pesquisa são sete servidores escolhidos num universo de aproximadamente 400 
auditores fiscais, cujos nomes citados neste artigo são fictícios para preservar suas identidades. Os critérios de seleção utilizados são: participação no trabalho, tempo de serviço, gênero, área de atuação, idade e interesse em participar da pesquisa. Escolhidos os sujeitos de pesquisa, foi criado o cenário de pesquisa (GONZÁLEZ REY, 2005). O estudo contempla quatro momentos empíricos, durante o período de julho de 2009 a fevereiro de 2010 , e os instrumentos de pesquisa foram a redação, a entrevista aberta e a conversação grupal, principalmente.

A pesquisa apoia-se na acepção de sentidos subjetivos de González Rey (2003), durante a qual são utilizados indicadores de sentidos subjetivos para o desenvolvimento contínuo de hipóteses, que serão confirmadas ou não no processo construtivo-interpretativo do conhecimento no decorrer do trabalho. Esse processo dá lugar a um modelo teórico em construção, permitindo a visualização, por via indireta, de informações ocultas aos sujeitos pesquisados. O processo de construção da informação não se orienta por uma lógica preconcebida, mas caracteriza-se por um processo mental e reflexivo do pesquisador, que ao longo da pesquisa vai construindo seu próprio modelo teórico. Nesse processo, o pesquisador busca acessar elementos de sentido que possam ser transformados em indicadores de sentidos subjetivos. Na medida em que esses elementos de sentidos e significados surgem, eles são agrupados em categorias, que servem como ferramentas de organização das informações.

A base para a captação dos sentidos subjetivos é a construção de hipóteses por meio dos indicadores de sentidos subjetivos. Um elemento essencial para a definição de um indicador de sentido subjetivo é a emoção expressa pelo sujeito. A emoção surge tanto nas conversações individuais quanto grupais, mas pode aparecer também em relatos escritos que favoreçam a livre manifestação dos sujeitos investigados e permitam uma expressão mais significativa. No que tange ao modelo teórico, ele não pode ser pronto e acabado, pois, durante o processo de pesquisa, pode haver transformações. O modelo vai se edificando ao longo da própria pesquisa e está relacionado às reflexões do pesquisador.

O relatório de pesquisa é o resultado do conhecimento produzido pelas interpretações do pesquisador dentro do modelo teórico desenvolvido. No relatório deste estudo, destacam-se as interpretações sobre os sentidos subjetivos do servidor fazendário ante a participação no trabalho, o que consiste na resposta interpretada dos pesquisadores ao problema estudado. O relatório não tem como objetivo apresentar conclusões, visto que, sob a perspectiva da epistemologia qualitativa, o conhecimento não representa um caminho que conduz ao descobrimento de algo pronto para ser conhecido ou de uma realidade que se apresenta de uma única forma. Como alerta González Rey (2005), o pesquisador precisa ter muito cuidado em suas afirmações, por isso, o relatório de pesquisa consiste 
na resposta interpretada do pesquisador ao problema estudado. O estudo de sentidos subjetivos sob a perspectiva da epistemologia qualitativa implica reconhecer que esse é um caminho, entre outros, para se chegar a uma realidade, cujos resultados são fruto do trabalho reflexivo e interpretativo dos pesquisadores, nos quais estão contidos os seus próprios sentidos subjetivos.

\section{"O POSTO, O IMPOSTO E O PASTO": PERSPECTIVA HISTÓRICO-CULTURAL DA SEFAZ}

A história da Sefaz inicia-se com a criação da Capitania Hereditária do Espírito Santo, no Brasil, cujo primeiro capitão donatário foi o fidalgo português Vasco Fernandes Coutinho (I490-I56I). Somente em I732 foi criada a Ouvidoria da Capitania do Espírito Santo, cuja jurisdição abrangia as vilas de Campos dos Goitacazes e de São João da Barra, na vizinha Capitania de Paraíba do Sul. A sujeição dessas vilas à Capitania do Espírito Santo foi motivo de protestos constantes de seus moradores, até que, em I82I, suas rendas foram desmembradas e, em I832, submetidas administrativamente à Província do Rio de Janeiro. Em I809, foi criada a Junta de Administração da Real Fazenda do Espírito Santo, subordinada diretamente ao Real Erário, no Rio de Janeiro, sistema que perdurou no período imperial. No período republicano, funções atuais da Sefaz eram executadas por um órgão chamado Tesouro, transformado em Diretoria de Finanças no governo Jerônimo Monteiro.

Em I920, no governo de Nestor Gomes, os serviços administrativos do Estado foram reformulados e foi criada a Secretaria da Fazenda. Nas décadas de I920 a I950, a secretaria funcionou no antigo Colégio dos Jesuítas, atual Palácio Anchieta. No dia 5 de julho de I962, no governo de Carlos Lindemberg, foi inaugurado o então moderno edifício Aureliano Hoffmann (Edifício das Repartições Públicas), para onde foi transferida a Secretaria da Fazenda.

Um marco importante da participação no fisco estadual foi a criação da Associação do Fisco Espírito-Santense (Afes), em 5 de março de I960. O início das atividades da Afes se deu num período de turbulência política no Brasil, com a eleição de Jânio Quadros e sua renúncia logo em seguida. Num clima de instabilidade política, João Goulart assumiu a presidência e em Ig 64 foi deposto pelo golpe de Estado, que instalou o regime militar no Brasil que durou até o ano de I985 (SILVA; REZENDE, 2009). 
Sempre que qualquer um de seus membros se insurgia contra os humores do Estado, sofria retaliações sérias. No caso do Fisco, havia constantemente o risco de uma atitude independente ser punida com a transferência do profissional para um município bem distante (SILVA; REZENDE, 2009, p. I7).

Com o fim do regime militar em I985, a participação da categoria cresceu significativamente. Questionavam-se as condições de trabalho, de segurança, a baixa remuneração e a baixa qualificação de grande parte dos fiscais. A grande conquista foi a realização de concurso público em i984, que renovou quase $40 \%$ do quadro de auditores. O processo de reivindicação por melhores condições de trabalho, remuneração e maior participação na Sefaz foi crescendo e o ápice veio em I988. Quando a Constituição Federal foi promulgada em outubro de i988, os fiscais estavam em greve. Era o governo de Max Mauro e acontecia a histórica primeira greve geral dos fiscais do Espírito Santo.

O movimento trouxe novas conquistas e abriu mais espaço à participação dos "fiscais novos" na gestão. Outra importante consequência foi a transformação da associação em sindicato, em I990, o Sindicato do Pessoal do Grupo de Tributação, Arrecadação e Fiscalização (TAF) do Estado do Espírito Santo (Sindifiscal). Essa discussão já havia sido iniciada em fins da década de ı980, mas sua concretização somente foi possível a partir de ı988, com o fim da proibição legal da existência de sindicatos no serviço público, proibição estabelecida pela ditadura militar. Outros dois marcos importantes de participação foram a criação, em I997, da Cooperativa dos Servidores do Grupo TAF do Espírito Santo (Coopfisco) e a fundação, em 2008, da Associação dos Fiscais Tributários do Espírito Santo (Afites).

\section{5 "[...] COMO SUJEITOS EM CAMINHADA": A CONSTRUÇÃO DO CONHECIMENTO}

O trabalho de campo se deu com a realização de quatro momentos empíricos. No primeiro, utilizou-se a conversação grupal, e, como indutor, foi solicitado a cada um dos participantes que contasse um fato que considerasse marcante em sua trajetória na Sefaz, associado à participação no trabalho. Os nomes utilizados a seguir são fictícios para preservar a identidade dos sujeitos. Carmem contou uma história tensa, sobre um fato acontecido no posto fiscal em que um caminhoneiro ameaçava se matar com um revólver, após ter sido multado pelos fiscais. O fato de a história ter se passado em um momento trágico pro- 
picia o surgimento de emoções a partir das quais emergem sentidos subjetivos. Chamam a atenção a rapidez e a espontaneidade de Carmem de se lembrar do fato e de associá-lo à necessidade pessoal de agir e mudar a situação de trabalho, característica de reflexibilidade e ação. Nas primeiras expressões de Carmem, já foi possível identificar um elemento central relacionado à família, mais especialmente em relação ao filho. A tensão e as dificuldades por que passou para conseguir a vaga no concurso foram substituídas pelo desafio de ter de se afastar do filho para trabalhar no plantão do posto fiscal.

Naquele momento trágico, durante alguns segundos fiquei perplexa, olhei em volta, pensei em meu filho, minha família, as dificuldades que tive para passar no concurso, as dificuldades no trabalho. Sei que por alguns segundos parei e pensei: “Carmem, o que você está fazendo aqui?”. Fato é que a partir daí passei a pensar mais no que fazer para melhorar a situação no trabalho.

Ana Lúcia lembrou que estava grávida quando passou no concurso em I984 e contou uma história que envolveu seu marido e um amigo dele, numa situação que atingia indiretamente sua profissão:

Nunca me esqueço de que havia um comerciante que sempre conversava com meu marido aquela conversa fiada de abordagens de fiscal, de propina [...]. Sei que um dia meu marido tomou minhas dores e conversou em tom severo com o comerciante [...]. A partir desse dia, a postura do comerciante mudou completamente. Aquilo de certa forma me mudou também, norteou um pouco meu comportamento no trabalho, pois, a partir daí, comecei a exigir mais respeito dos outros em relação a mim e aos meus colegas. Talvez falte um pouco disso em nossa profissão de fiscal.

Na fala de Ana Lúcia, florescem sentidos subjetivos muito fortes, que parecem estar associados à sua condição de mãe, de esposa e de mulher diante do universo masculino dominante no campo da fiscalização. O apoio da família e do marido a motivou a exigir mais respeito no trabalho, o que pode indicar que ela até então não se sentia respeitada. Sua atuação no ambiente de trabalho parece estar fortemente associada ao sentido subjetivo afetivo familiar.

Vera lembrou suas dificuldades para adaptação à vida no posto fiscal, lembrou a colega falecida em acidente de carro no trabalho, que parece ter superado com o tempo, e mostrou inquietude demasiada em relação aos chefes que teve, que não souberam lidar com os novos servidores fiscais, em sua opinião. As expressões de Vera são caracterizadas pelo trânsito espontâneo e aberto em elementos que 
parecem residir em seus variados espaços sociais e que se misturam no trabalho: o namorado, a juventude, a minissaia, o jovem e o velho, os colegas, a garotada, a aventura, a condição feminina: "fato é que apenas muito tempo depois consegui analisar melhor aquele momento. Acho que éramos muito jovens!".

Plínio lembrou o episódio de seu primeiro dia de trabalho, no qual aparece especialmente sua preocupação com o desenvolvimento pessoal. A intenção de abandonar o trabalho, caso a profissão o impedisse de estudar, é um indicador forte de sentido subjetivo associado ao desenvolvimento pessoal, mais importante do que o próprio emprego e da sua fixação na terra natal. Em busca de seus objetivos, faria o que fosse preciso, inclusive "passar" por cima do chefe imediato e conversar diretamente com o dirigente maior da instituição:

Nos meus primeiros plantões no posto fiscal [...], meu pai me levava. A primeira vez, sinceramente, eu quase voltei com ele mesmo. Não queria nem entrar no posto fiscal. Passado algum tempo, decidi que não continuaria trabalhando se para isso tivesse que abrir mão do curso superior na Ufes, em Vitória. [...] aquela conversa direta com o secretário, numa época em que falar com um secretário da Fazenda parecia coisa de outro mundo, influenciou, de certa forma, minha permanência e de certa forma minha forma de atuação na Fazenda.

Nas primeiras expressões de Gabriel, aparecem elementos associados à sua visão de mundo, caracterizada pela preocupação com a condição social do outro. O conflito interno entre a visão social de mundo e a preocupação em dar satisfação ao chefe pode revelar também um indicador não de respeito, mas de certo afastamento ou frustração em relação aos superiores. Em Gabriel, aparece preocupação forte com o valor agregado por sua atuação no trabalho:

Logo no início na Fazenda, eu e um colega fomos destacados para fazer uma fiscalização num determinado bairro de Colatina. Chegando ao local, observamos que se tratava de uma "birosca", numa rua quase deserta de construções. Ficamos dentro do carro olhando aquilo, aquela mulher simples com o filho no colo, aquelas pequenas coisas à venda, e pensando no que fazer. Conversamos alguma coisa e retornamos, mas fui pensando numa resposta para a chefia.

Nesse primeiro momento empírico, floresceram indicadores de sentidos subjetivos bem variados em cada um dos sujeitos de pesquisa, mas, como a pesquisa apenas se iniciava, ainda era muito cedo para começar a construção de hipóteses de sentidos subjetivos, que passariam a ser levantadas a partir do momento seguinte. É possível perceber que os relatos desse primeiro momento 
aparecem soltos pela forma espontânea das conversas. Na perspectiva da epistemologia qualitativa, o pesquisador toma a coordenação do grupo de pesquisa, porém da forma menos incisiva possível, procurando fazer com que as conversas orbitem o tema estudado. A partir dos momentos seguintes, os indicadores de sentidos subjetivos vão sendo organizados e transformados em hipóteses, o que é feito mentalmente pelo pesquisador, qualitativamente, dentro do "modelo teórico" que ele vai construindo ao longo da pesquisa.

\section{1 "O EXPEDIENTE TEM DE COMEÇAR NO HORÁRIO INICIAL E TERMINAR NO PROGRAMADO"}

No segundo momento empírico, a conversação teve início de maneira bastante informal, numa discussão muito acalorada, iniciada por Ana Lúcia, ao relatar que, em determinados dias, precisava permanecer bem além do expediente normal de trabalho para terminar tarefas do setor. Egberto pede licença para fazer algumas considerações e daí a conversa em grupo flui.

Egberto: Ana Lúcia, preste atenção, mas preste atenção mesmo. Nós fomos admitidos em condições precaríssimas de trabalho e passamos a fazer muito mais do que o Estado tinha condições de nos dar. Mas hoje precisamos ter consciência disso.

Ana Lúcia: Eu sei, Egberto, e ninguém me pede para fazer isso, mas é que existem processos que precisam ser finalizados e não tenho como ir embora...

Plínio: Tem uma falha aí no dimensionamento do pessoal. O expediente tem de começar no horário inicial e terminar no programado, e dar tempo de fazer o trabalho a ser executado.

É possível perceber elementos distintos nos três sujeitos envolvidos na discussão. Egberto revela indignação diante do problema colocado por Ana Lúcia, sentidos que ganham força em seu jeito de falar, enquanto Ana Lúcia demonstra acomodação diante da situação. Plínio prefere assistir calmamente à discussão e, durante esse tempo, demonstra estar pensando numa solução mais simples, política, que esteja entre a resignação de Ana Lúcia e a indignação de Egberto. Em sua fala, aparece reverência ao aspecto legal e às regras administrativas, mas sobretudo o cuidado e a conduta política diante de situações complexas ou conflituosas. Inácio apresenta elemento associado à defesa do profissionalismo nas relações institucionais que está ligado à necessidade que vê de desvinculação dos novos auditores da geração anterior e da cultura da organização, baseada em relações de amizade, em sua opinião. 
Carmem: A falta de reconhecimento é o principal.

$[\ldots]$

Egberto: Posso abrir um parêntese? Sabe que filme você me lembrou? A fuga das galinhas. Uma das galinhas imaginou que pudesse sair do galinheiro voando: "Dá pra gente voar, hein?”. “Que nada”, disseram outras, “não dá pra voar é nada!”. Plínio: Nós entramos no Estado pensando muito mais no controle que a administração tinha sobre nós, do que no que podíamos produzir para o Estado. Nós entramos no posto fiscal e não podíamos nem sair, mesmo que não tivesse nada por perto, ficávamos ali vigiando o nada. [...] Em relação a vocês que são mais novos, infelizmente, aquilo que não gostávamos que fizessem conosco continuamos a fazer com vocês. A gente ocupou o lugar daqueles que nos controlavam e passamos a fazer o papel deles, controlando os que vieram depois de nós. Vocês estão agora no lugar em que nós nos encontrávamos quando entramos no Estado.

Assim como na fala anterior de Inácio, a prontidão na fala de Carmem e o elemento novo revelado, a falta de reconhecimento, permitem levantar o indicador de sentido subjetivo em Carmem da necessidade de reconhecimento. É interessante ver como são diferenciados em cada um os sentidos subjetivos associados à participação no trabalho. É possível que Carmem guarde consigo alguma experiência no trabalho negativa forte em relação à falta de reconhecimento ou então que isso esteja ainda em curso. Esse significado apareceria novamente em suas expressões: "É isso mesmo, a falta de reconhecimento magoa muito". A emoção em "magoa muito" reforça o indicador da necessidade de ser reconhecida no trabalho, que pode estar muito acima da participação nas decisões, por exemplo.

Plínio faz uma fala incisiva, autocrítica e corajosa que reforça a ideia de controle exercido pela geração de auditores de i984. Essa espécie de censura social, ou controle cultural, e a amizade sobreposta às relações de profissionalismo vão se reforçando como aspectos relevantes da subjetividade social na instituição. Inácio apresenta um indicador de sentido subjetivo relacionado à restrição que sente no tocante à sua atuação na instituição. Egberto responde a Inácio, expressando-se ancorado por sua visão de mundo. Um aspecto muito importante associado à participação no trabalho aparece quando alguns sujeitos de pesquisa fazem críticas ao planejamento estratégico, apelidado de "caderninho", mas parece não ser uma crítica direta ao planejamento, mas à falta de participação das pessoas na sua elaboração, que não aparece de forma direta nas expressões dos sujeitos, constituindo um indicador de sentido subjetivo mais forte em Inácio e Egberto, mas também nas expressões de Gabriel e Vera. Egberto traz à tona 
elementos que integrados revelam sua visão de mundo, na qual a preocupação com o trabalho e com o trabalhador se destaca, continuando o debate travado com Inácio e reforçando indicadores de sentidos subjetivos levantados.

Egberto: Inácio, você tocou num ponto que é a alienação no trabalho. Você tocou numa questão muito profunda e muito séria. A alienação no trabalho está conosco desde a Revolução Industrial. As pessoas fazem as coisas no dia a dia e não conseguem vislumbrar o alcance delas, e nós não estamos imunes a essa sensação da alienação no trabalho. Isso que você está sentindo, o cara que está lá na fábrica, o dia inteiro, apertando a porca, sente. Ele não participou do projeto do carro e nem das outras etapas da construção do carro. Ele não sabe a cor do farol do carro. Então, isso que você está sentindo, não se preocupe. O nível dessa alienação depende da posição que o trabalhador ocupa na fábrica. Se ele é gerente, ele pode ter participado do projeto, conhecido as etapas da construção do carro, das vendas, das compras das peças, mas o trabalhador do chão da fábrica é um alienado, pois não conhece o produto como um todo. O gerente está tendo uma visão...

Inácio: Global...

Egberto: Isso, então ele sofre menos as dores da alienação no trabalho. Ele está enxergando da torre. Então, essas questões que você está tocando são tão antigas quanto a sociedade industrial.

\section{2 "AH, ME LEMBRO COMO SE FOSSE HOJE!"}

No terceiro momento empírico, utilizou-se o instrumento de redação, e o indutor foi a solicitação para que cada um dos sujeitos de pesquisa escrevesse brevemente sobre sua identidade, seus gostos, sua trajetória na Sefaz e o que mais julgasse interessante. Os perfis levantados constituíram elos para a análise das expressões identificadas nos outros momentos empíricos. Os dados obtidos nesse terceiro momento empírico serviram mais como apoio ao estudo dos momentos empíricos anteriores, já que a redação não possibilita o florescimento de sentidos subjetivos tão significativos quanto a conversação, por exemplo. Gabriel traçou seu perfil, sua história como estudante de economia na terra mineira natal e as atividades desenvolvidas até os 30 anos, quando foi aprovado para o concurso na Sefaz. Falou também de seu início no trabalho, do dia, mês e ano em que foi admitido e de suas atividades realizadas na Sefaz. Destacou o seu trabalho e de outros colegas para "salvar o concurso". A expectativa em assumir o cargo era muito grande. 
[...] o trabalho era tão sério e bem visto que muitas vezes éramos ajudados financeiramente por outros aprovados, que somente nos conheciam por meio da internet e, às vezes, por telefone. [...] Conseguimos sucesso em nossa empreitada.

Plínio apresentou um texto bastante formal, em terceira pessoa. Interessante é que o aspecto da formalidade e não do conteúdo foi o que mais contribuiu para reforçar sentidos subjetivos que vinham sendo estudados nas expressões de Plínio, trazendo à tona o potencial do referencial teórico, epistemológico e metodológico utilizado. Carmem fez uma redação curta e simples, mas não deixou de mencionar o estado civil e o filho. Inácio foi mais longe e, com um texto intitulado "Minha vida na Fazenda”, que acabou inspirando o título deste artigo, colocou no papel expressões reveladoras de sentidos subjetivos variados e muito significativos. Sua redação foi a que mais contribuiu para reforçar indicadores e hipóteses que vinham sendo estudadas em suas expressões. Falou dos empregos antes de assumir o cargo de auditor, de sua atuação na tecnologia da informação, da experiência complicada como estivador, da luta para passar no concurso. "Aí o coração apertou”, disse em relação ao risco de cancelamento do concurso; “Ah, me lembro como se fosse hoje", em relação à posse com outros colegas e com a presença de familiares. Mas finaliza com expressões que denotam decepção: "não acreditava que havia estudado tanto para fazer um serviço tão aquém do meu conhecimento, e ainda estar numa instalação indigna para qualquer trabalhador, ainda mais para auditores do Estado".

Ana Lúcia, Egberto e Vera não entregaram suas redações, mas, durante os outros momentos empíricos, foram falando de seus perfis. Egberto se expressa com muita eloquência, mas também com muita política e polidez. Como Inácio, revela bastante decepção com o início da carreira, pois acreditava que poderia ter contribuído muito mais para a instituição e, curiosamente, para as próprias empresas fiscalizadas, por causa de sua formação acadêmica específica no campo da engenharia industrial. É interessante que sua decepção se parece com a de Inácio, apesar de os dois inícios de carreira estarem separados por mais de vinte anos.

\section{"AÍ EU DISSE: 'QUE COISA LINDA, FILHO!'"}

Passados três momentos empíricos, indicadores de sentidos subjetivos e hipóteses já haviam sido levantados, e era possível perceber que as conversas em torno do tema pesquisado começavam a dar sinais de esgotamento, indício de que a pesquisa caminhava para um final. O quarto momento empírico serviu para consolidar conhecimentos levantados e se deu novembro de 2009 . Para 
essa reunião, foram preparados indutores específicos com o objetivo de obter informações complementares às expressões reveladas pelos sujeitos de pesquisa nos momentos empíricos anteriores. A conversa começou com Carmem, que relembrou os períodos difíceis estudando para o concurso, a ausência do filho de 3 anos, a amiga que desistiu e a própria persistência. A menção ao filho reforça o gênero e o sentido de maternidade como hipótese de sentido subjetivo associado à sua participação no trabalho.

Ana Lúcia foi incitada a relembrar a situação contada no início da pesquisa, mas acabou por fazer uma revelação que foi fundamental. Ao revelar um almoço que teve com o filho, a forma como o fez, a riqueza de detalhes e a importância que deu àquele momento, reforçou a hipótese de sentido subjetivo da participação no trabalho associado ao núcleo familiar. A expressão mais reveladora está na frase "Que coisa linda, filho!", repleta de emoção. Essa hipótese apareceu com mais força em Ana Lúcia no início da pesquisa, mas foi se perdendo no meio de outras expressões em outros momentos. Diferentemente de outros sujeitos, em que indicadores foram sendo consolidados, em Ana Lúcia, indicadores ora se firmavam, ora se enfraqueciam, dificultando as interpretações. Esse "vaivém" da construção do conhecimento é uma característica da epistemologia qualitativa: um único momento pode consolidar ou desconstruir indicadores e hipóteses de sentidos subjetivos levantados.

Plínio foi provocado a falar sobre seu desenvolvimento na carreira, e, em sua fala, aparecem logo a figura do pai, a terra natal e a área onde gostaria de atuar na Sefaz. Plínio reforça elementos associados à regra, à disciplina, à organização. Sua fala reforça também elementos associados à condição de igualdade perante o outro e, mais do que isso, mostra preocupação com a pessoa a quem serve com seu trabalho: "por isso o cuidado na elaboração de uma lei deve ser grande, pela amplitude das consequências que produz".

Solicitou-se a Gabriel que mencionasse alguém que admirasse na Sefaz e qual cargo escolheria se tivesse que assumir um novo posto. Questionado sobre um exemplo de gerente, cita um colega, mas lembra primeiro a importância que o colega dá à família. Trata-se de um indicador novo, mas muito forte pela forma indireta como o faz de sentido subjetivo da participação no trabalho associado à família. Ao falar sobre o sentimento de evolução dos chefes, Gabriel reforça a frustração em relação à forma de atuação de alguns dirigentes com quem conviveu.

Egberto foi questionado sobre uma possível intenção em atuar em sua profissão original, mas o elemento que apareceu vivo em sua fala está associado ao seu ideal de mundo: "um ano depois estava com a cabeça completamente virada, pela conjuntura que o país vivia na época, por volta dos anos 70 ”.

Vera foi provocada a falar sobre o significado que vê em sua profissão hoje e o que tinha mudado desde seu ingresso em ig84. As expressões de Vera reme- 
tem novamente ao conflito interno entre a atuação na área técnica e numa área voltada aos recursos humanos na instituição, reforçando a frustração em não atuar numa área mais próxima às suas aptidões. Faz uma crítica aberta à falta de atenção aos recursos humanos: no papel um modelo novo, mas na prática um modelo antigo, em sua opinião, apesar de acreditar que mais recentemente isso esteja mudando.

As últimas expressões desse último momento empírico focam a primazia que as relações de amizade têm sobre o profissionalismo na instituição. Apenas Inácio se posiciona fortemente contra essa situação, o que pode ser considerado um aspecto importante da subjetividade social reinante na instituição, ao lado do aspecto relacionado ao controle e à falta de comunicação e participação, elementos que se relacionam. Egberto analisa a cultura da amizade como uma herança que a geração de 1984 herdou das gerações anteriores. A reunião foi suspensa e sua continuidade foi programada para quando as interpretações dos dados obtidos até aquele momento estivessem avançadas, o que foi feito em fevereiro de 20I0. Nessa reunião, apenas Plínio e Carmem não puderam participar. $\mathrm{Na}$ ocasião, foi apresentada aos sujeitos de pesquisa uma cópia do estudo, explicando os sentidos subjetivos mais expressivos identificados em cada um deles ante a participação no trabalho. A reunião encerrou o quarto momento empírico e representou o fim da fase empírica da pesquisa.

\section{"A VIDA NA FAZENDA": OS SENTIDOS SUBJETIVOS DA PARTICIPAÇÃO NO TRABALHO}

Finalizados os momentos empíricos, tornou-se possível, dentro da lógica do modelo teórico em construção desde o início da pesquisa, apresentar as interpretações inerentes ao objetivo da pesquisa: compreender os sentidos subjetivos do servidor fazendário ante a participação no trabalho. Foi possível também compreender aspectos da subjetividade social no espaço de trabalho da instituição, que influenciam sentidos subjetivos dos sujeitos, ao mesmo tempo que essa subjetividade social é pressionada pela subjetividade individual dos servidores.

Os sentidos subjetivos essenciais de Carmem ante a participação no trabalho se associam à família - especialmente ao filho - e ao gênero, ao se encontrar no campo de dificuldades da mulher como mãe, trabalhadora e dona de casa, problema enfrentado pelas mulheres de modo geral, mas de onde parecem originar elementos associados à resistência e à superação de desafios. Carmem sente necessidade de ser reconhecida: o prêmio pelo empenho é o reconhecimento, sem o qual não teria valido a pena o esforço empregado. 
Egberto apresenta sentidos subjetivos associados à visão político-filosófica de mundo, na qual a preocupação com o trabalho e com o trabalhador se destaca. A necessidade de participação em tarefas e decisões complexas e estratégicas está presente em suas expressões. Egberto denota a atuação ativa do sujeito, processo alimentado pelo exercício da reflexibilidade e do gosto pelo debate, pela política e pela dialogia, por isso ressente-se da falta de fóruns de participação e de discussão na instituição.

Nas expressões de Ana Lúcia, aparecem principalmente sentidos subjetivos associados ao núcleo familiar, no qual parecem residir afetos intensos em relação aos filhos e ao marido. Em certos momentos, parece tentar reproduzir, no espaço do trabalho, sensações do espaço familiar. Ana Lúcia parece conceber o plano de, pela família, seguir até o último dia de trabalho, no qual terá a redenção e a volta "definitiva" para o espaço familiar. Suas expressões apresentam elementos associados à condição de mulher diante da predominância do universo masculino no trabalho, mas também à ação como sujeito, gerada a partir do sentido da necessidade de ser respeitada. Ana Lúcia revela frustração em não poder participar mais ativamente de processos de decisão que abrangem seu setor, elemento associado à conduta participativa que procura ter em seu espaço de trabalho, como forma inclusive de "ganhar a confiança e a simpatia das pessoas", como diz. É o sujeito construindo teoria.

Em Plínio, o desenvolvimento profissional e cultural parece constituir sentido subjetivo fortemente associado à sua participação no trabalho, mas parece se integrar a um sentido subjetivo maior, relacionado à necessidade de se desenvolver integralmente como pessoa humana. Assim, a busca por desenvolvimento em diversas áreas parece funcionar como instrumentos para esse desenvolvimento maior. As expressões de Plínio e a forma como faz, caracterizada pela atenção voltada a ouvir o outro e pelo cuidado excessivo em não afetar quem quer que seja, configuram sentidos subjetivos que se misturam com uma atuação muito reflexiva. Mais do que a ação, o sentido subjetivo da reflexão molda sua atitude como sujeito e parece influenciar fortemente sua participação no espaço do trabalho. Suas expressões denotam também um senso de igualdade muito forte perante o outro. A referência ao aspecto legal é outro elemento central em suas expressões, o que muito provavelmente é fruto de sua atuação nessa área na instituição. Plínio tem alto senso de respeito às normas legais e às regras, e, paradoxalmente, aversão a controles que possam ser exercidos sobre si ou outrem, pois, em sua opinião, as instituições devem prezar a busca por resultados voltados para a sociedade.

Os elementos encontrados na complexa produção de subjetividade em Vera permitem destacar os sentidos subjetivos ante a participação no trabalho relacio- 
nados à busca permanente pelo novo, pela mudança, no qual estão associados sentidos caracterizados por sua atuação permanentemente jovial, aberta e alegre. É possível também levantar sentidos subjetivos associados à atuação como sujeito autônomo: a autonomia parece preponderar em Vera. É possível perceber relativa frustração em não atuar numa área mais próxima à de sua formação ou aptidão dentro da instituição, bem como relativa frustração diante da ausência de participação sua e de seus colegas em discussões importantes para a instituição.

Vera parece estar sempre se questionando sobre sua participação no trabalho, sobre seu papel, sobre o que faz ou o que deveria estar fazendo, e esses elementos parecem gerar conflito interno em sua atuação profissional. A opção pela atuação na área técnica e a demonstração direta de gosto pelo que faz atualmente parecem estar em permanente conflito com sua vocação e formação original, orientada mais para a área humana. Esse conflito pode ser identificado principalmente quando fala da necessidade de buscar motivação interna, o que equivale à necessidade de produzir novos sentidos subjetivos, para seguir em frente no trabalho, após ter chegado ao topo da carreira. É possível levantar, em suas expressões, sentimento de frustração pelo trabalho executado atualmente, e dois indicadores indiretos permitem a afirmação desse sentido:

I. Vera está numa atividade muito técnica para alguém com formação voltada para a área de humanas.

2. Ela executa tarefas que não se ajustam a sentidos subjetivos associados ao novo, à jovialidade, à mudança, pois algumas seguem padrões obsoletos, estabelecidos há mais de quarenta anos.

Agregue-se a isso a dificuldade em lidar com técnicas e ferramentas novas, principalmente ligadas à informática, e a consciência de que poderia estar contribuindo melhor em outra área.

Gabriel, em vários trechos de suas expressões, revela simplicidade e visão social própria. A família não é muito citada, mas a forma como o faz reforça sentidos subjetivos associados à influência que o núcleo familiar tem em sua participação no trabalho e provavelmente em outros espaços sociais. A partir da integração de elementos levantados em suas expressões, é possível desenhar sentido subjetivo associado à visão social de mundo, cujos elementos principais são a preocupação com a "situação de vida" do outro: "aquela mulher com a criança no colo". Deriva daí a busca por cumprimento fiel de tarefas que lhe são incumbidas, mas também um sentimento de respeito e afastamento em relação a ordens e diretrizes que não coadunam com a visão social que tem. Suas expressões revelam relativa frustração pelo exercício de funções ou execução de 
tarefas nas quais não consiga identificar geração de valor para a instituição e para a sociedade, sentidos que guardam relação com sua visão social. Aparecem também, em suas expressões, elementos ligados à necessidade de participar em trabalhos em equipe e à aptidão para o exercício de liderança. Antagonicamente, algumas expressões diretas como "tenho aversão a ser chefe" parecem fortalecer um espírito de liderança. Gabriel também se ressente do controle cultural na instituição, que parece reprimir sua participação no trabalho, bem como a de seus colegas, em sua opinião.

Inácio, já em sua primeira fala, assume uma postura bastante crítica e determinada em relação ao assunto em discussão: a mistura exagerada entre amizade e profissionalismo no ambiente de trabalho. Inácio foi entre os participantes o que mais investiu contra o que considera ser relativo "controle cultural" imposto pela geração de auditores do concurso de I984, sobre a geração de 2005 . É possível levantar em Inácio sentidos subjetivos ante a participação no trabalho associados à autoestima; à valorização que dá à sua história e trajetória de vida; à sua capacidade, dedicação e persistência em busca de objetivos, no trabalho e em outros espaços sociais. A autoestima parece configurar um sentido subjetivo central que estrutura a participação de Inácio no trabalho, associado à ação proativa como sujeito, do qual derivam elementos associados à posição autônoma e decisiva diante de assuntos críticos. Aparecem, em suas expressões, elementos relacionados à necessidade de mudança rumo ao moderno, sentidos que parecem advir do gosto por sua área de formação e atuação, a tecnologia da informação. Inácio percebe a necessidade de a instituição avançar, mas vislumbra que esse avanço somente vai acontecer pela geração mais nova, em sua opinião. Inácio percebe mais nitidamente os laços fortes de amizade construídos pela geração de auditores de I984, que se misturam muito com as relações de trabalho, fruto muito provavelmente de longos anos sem concurso público na Sefaz, como revelou Egberto. Inácio sente necessidade de trabalhar de forma integrada e contextualizada e de superar valores ligados ao controle e à falta de debate e de participação na instituição. Também se integra a esse sentido a frustração por não participar de decisões em nível estratégico, ainda que não investido em cargo hierárquico. Nesse contexto, aparecem elementos associados à separação entre administradores e administrados; entre o novo, o planejamento, e o velho, a falta de discussão na instituição.

Nas expressões dos sujeitos, é possível perceber constantemente a tensão recíproca entre a subjetividade social e a individual. Nos momentos empíricos, pode-se enxergar o sujeito a todo instante estudando o espaço social em que vive, lutando contra a pressão exercida pela subjetividade social sobre a subjetividade individual, buscando alternativas para viver nesse espaço, mas, ao mesmo 
tempo, pressionando-o e tentando modificá-lo, numa tentativa de impor ou defender sua própria subjetividade. Os resultados da pesquisa mostram que a produção de sentidos subjetivos se dá em diferentes espaços de convívio social e que esses sentidos estão de fato presentes nas experiências do sujeito. Permitem ainda entender a subjetividade social construída a partir de complexas relações e interações de sentidos subjetivos, resultando num grande sistema de sentidos subjetivos. Nas expressões dos sujeitos, observa-se a cada momento a relação intrínseca entre a subjetividade individual e a social; uma pressão recíproca, constante e sem fim. Nesse processo, a divisão entre o social e o individual inexiste, assim como a dicotomia entre o social e o subjetivo.

Essas interpretações vão ao encontro da visão histórico-cultural de Gonzalez Rey (2003) de subjetividade. Algumas interpretações específicas ajudam a compreender esse processo tenso entre a subjetividade social e a individual, entre o sujeito e sua participação na instituição. Por exemplo, a visão política de sociedade em Egberto, originada em um período da história do Brasil relacionado ao regime militar iniciado em I964, parece influenciar a produção de sentidos subjetivos associados à sua participação no trabalho, sentidos relacionados ao vislumbre por uma instituição mais aberta, vibrante, democrática, política e participativa. Já em Inácio, a autoestima, fruto provavelmente de conquistas importantes que teve e tem tido em sua história de vida, parece constituir sentido subjetivo que estrutura sua participação no trabalho e sua relação com aspectos relevantes da subjetividade social na instituição. Em Plínio, quando se analisam suas expressões diretas, a subjetividade individual é reprimida pela subjetividade social, mas isso pode não passar de aparência. O sentido subjetivo associado à atitude reflexiva como sujeito, que lhe parece constituir sentido subjetivo essencial nos vários espaços de sua atuação como sujeito, permite dizer que, entre os sujeitos pesquisados, Plínio seja talvez o mais descolado da subjetividade social.

Os resultados evidenciam que o espaço do trabalho não é independente de outros espaços sociais e que geram formas de subjetivação que se materializam nas diferentes atividades compartilhadas pelos sujeitos no ambiente do trabalho pesquisado. Mostram que o sujeito está constantemente em processo de reflexão sobre como a subjetividade social e a individual, a sua própria e a dos outros, atingem-no. Com base nas análises que faz, compartilha com outros sujeitos, participa intensamente nessa tensão entre o individual e o social, utilizando como instrumentos a expressão e a ação. As interpretações de cada sujeito em relação ao ambiente institucional e à participação no trabalho são variadas, pois nelas estão refletidos sentidos subjetivos diversos, derivados de seus diferentes espaços sociais de atuação (o cultural) da vida "vivida" de cada um (o histórico). 


\section{"DO SÍTIO AO SITE": CONSIDERAÇõES FINAIS E O RECONSTRUIR DE UMA OUTRA INSTITUIÇÃO}

Este artigo teve como objetivo compreender os sentidos subjetivos do servidor fazendário ante a participação no trabalho. O referencial teórico é a teoria da subjetividade sob o enfoque histórico-cultural (GONZÁLEZ REY, 2003). O método de pesquisa é o estudo de caso (GONZÁLEZ REY, I999), e a pesquisa é de natureza qualitativa, cuja interpretação e construção da informação são feitas em uma perspectiva epistemológica implícita na teoria da subjetividade e na epistemologia qualitativa (GONZÁLEZ REY, 2003, 2005).

O conceito de sentido subjetivo possibilita a produção de conhecimentos sobre a instituição pesquisada que dificilmente poderiam ser acessíveis por meio de métodos empíricos tradicionais. A epistemologia qualitativa, sobretudo no destaque que concede à singularidade, mostrou-se promissora para o estudo da instituição pesquisada. A atenção aos significados e às emoções contidas nas formas de comunicação dos sujeitos de pesquisa permite a identificação de elementos que integrados conduzem à descoberta de sentidos subjetivos que estruturam a vivência dos sujeitos e sua participação no trabalho na instituição.

A abordagem teórica desenvolvida por González Rey $(2003,2005)$ revelou seu potencial nesta pesquisa ao propiciar a emergência de conhecimento acerca do problema estudado, que dificilmente seria possível por meio de abordagens mais diretas, ainda que dentro de uma perspectiva qualitativa de pesquisa. Foi possível compreender a epistemologia qualitativa como uma abordagem nova e diferente, com potencial enorme para o estudo de problemas organizacionais, situados na preocupação com o outro, com a pessoa e com sua subjetividade.

Os autores deste artigo alertam, no entanto, sobre as dificuldades encontradas no curso da pesquisa. A primeira diz respeito à própria compreensão da perspectiva teórico-metodológica de González Rey (2003, 2005), que se afasta de raciocínios objetivistas, não raramente encontrados na pesquisa qualitativa. A segunda dificuldade não é menor e refere-se à condução dos momentos empíricos. É preciso muito cuidado ao lidar com os sujeitos de pesquisa, e, para isso, a condução de cada momento empírico deve ser feita com muito esmero, a fim de que não se percam a confiança do grupo em relação ao pesquisador nem o foco no tema e no problema investigado. As interpretações de cada momento empírico necessariamente não são realizadas de forma sequencial, o que dificulta o desenvolvimento da pesquisa e sua própria compreensão por parte do leitor interessado. Muitas vezes, durante o curso da pesquisa, é necessário voltar 
para reinterpretar dados passados, por causa das informações novas obtidas em momentos presentes.

A terceira dificuldade parece maior ainda e diz respeito à compreensão do próprio significado de sentido subjetivo. Os autores deste artigo acolhem o mérito de terem atingido na pesquisa aproximações relevantes em relação a elementos conceituais implícitos na epistemologia qualitativa, mas reconhecem sua dificuldade de compreensão mais profunda em relação sobretudo ao significado de sentido subjetivo. Acreditam que a superação dessas dificuldades virá com o desenvolvimento de novas pesquisas no campo dos estudos organizacionais baseadas nessa proposta, em que epistemologia, teoria e metodologia se integram.

No que tange aos resultados, pode-se verificar o espaço de trabalho como um ambiente gerador de subjetividade. As relações do sujeito nos diversos espaços sociais onde atua produzem constantemente sentidos subjetivos que afetam esses diferentes ambientes em que vive, ao mesmo tempo que o sujeito também é afetado pela subjetividade desses espaços. Dessa forma, torna-se compreensível a impossibilidade de separar espaços sociais uns dos outros. O estudo de um espaço social, sob a perspectiva da epistemologia qualitativa e a partir da compreensão do sujeito dentro de uma teoria histórico-cultural de subjetividade, requer atenção aos demais espaços de atuação dos sujeitos pesquisados e de sua história.

Foi possível verificar ainda a importância do sujeito individual como via de acesso indispensável à compreensão científica de uma realidade social. Os sujeitos pesquisados fornecem dados valiosos e fundamentadores do conhecimento sobre a Sefaz. Além dos sentidos subjetivos, os resultados possibilitam a identificação de elementos marcantes da subjetividade social prevalente na instituição. Os resultados mostram, por exemplo, o estrago provocado pela falta de ingresso de novos servidores na instituição durante mais de vinte anos, edificando, por exemplo, o elemento da separação entre "novos e antigos".

As interpretações dos diálogos entre os sujeitos da pesquisa permitem levantar aspectos importantes que permeiam a instituição, dentre os quais podem-se evidenciar a ausência de projetos que busquem estimular os servidores; o excesso de burocracia na gestão e nos processos de trabalho; a falta de instrumentos para utilização dos conhecimentos adquiridos no desenvolvimento das tarefas; a insuficiente comunicação entre os componentes da instituição e entre dirigentes e dirigidos; a carência de relações entre os profissionais e o setor onde desenvolvem as tarefas; e a falta de formação profissional e de diálogo entre os próprios membros das equipes de trabalho. Trata-se de indicadores que parecem importantes para o estudo da instituição pesquisada, bem como de outras administrações públicas. 
A pesquisa revela o anseio dos sujeitos pesquisados pela construção de uma nova instituição e permite levantar sugestões importantes para tal. Entre as mais importantes, destacam-se o estabelecimento de uma política de recursos humanos em médio e longo prazos e o incremento de espaços de participação na instituição. A qualidade de vida no trabalho e fora dele e o problema da condição da mulher no espaço de trabalho fazendário são questões que precisam ser tratadas com prioridade. O cuidado com o servidor em início de carreira e o fortalecimento de relações baseadas na confiança e no profissionalismo devem substituir respectivamente os aspectos controle e amizade, fortemente impregnados na subjetividade social da instituição. Os resultados revelam a necessidade de se dar maior importância à individualidade, pois essa carência parece ser um elemento vivaz que alimenta os aspectos mencionados da subjetividade social no ambiente de trabalho. É possível perceber que um dos fatores decorrentes dessa falta de atenção é o relativo sentido de separação existente na instituição entre dirigentes e dirigidos, velhos e novos, novo e arcaico, uma repartição e outra.

Epistemologicamente, considera-se relevante o ineditismo da aplicação da epistemologia qualitativa (GONZÁLEZ REY, 2005) e da teoria da subjetividade sob o enfoque histórico-cultural (GONZÁLEZ REY, 2003) em pesquisas no campo da gestão pública com foco no servidor e em sua participação no trabalho. A concepção de subjetividade do autor confirmou-se promissora para a realização da pesquisa, coadunando com a opinião de Paes de Paula e Palassi (2007) sobre o potencial dessa concepção de subjetividade para os estudos organizacionais. Este estudo deixa perguntas, entre outras tantas, que podem ser objeto de investigação:

- Qual é o impacto exercido pela percepção de controle na participação no trabalho e na eficiência institucional?

- Como esse controle é percebido por outros servidores que integram a instituição, além dos auditores fiscais?

- Como está constituído o problema relacionado ao gênero, especialmente em relação à mulher, no espaço fazendário?

Este artigo apresenta apenas uma aproximação ao complexo sistema de relações que dá forma à instituição pesquisada, um acesso parcial e limitado a práticas associadas à participação no ambiente de trabalho. Ademais, os resultados representam a interpretação dos autores deste artigo sobre as expressões dos sujeitos pesquisados, expressões e interpretações influenciadas pela história de vida e sentidos subjetivos dos sujeitos envolvidos na pesquisa, inclusive os dos pesquisadores, em compatibilidade com a epistemologia qualitativa empregada que considera inviável a neutralidade do pesquisador. Os resultados, apesar do 
conteúdo crítico, devem ser vistos como subsídios para a reconstrução da instituição. Carregam em si a vontade dos participantes do estudo de contribuir para o desenvolvimento integral dos que compõem a instituição, sem exceção, e de colaborar para o aprimoramento das relações de trabalho e da participação na Sefaz. A expectativa maior é que o trabalho concorra para o apontamento de medidas voltadas ao desenvolvimento de uma instituição fazendária cada vez mais democrática, participativa e capacitada para atender às expectativas e demandas do cidadão.

\section{TREASURY LIFE: SUBJECTIVE SENSES OF THE WORKER IN THE LIGHT OF THE PARTICIPATION AT WORK}

\section{ABSTRACT}

The research problem had its origin because of the uneasiness of the researchers about the diversity and complexity of the problems related to the participation at work, hard to be always explained via objective elements. This understanding of the problem guided the option for a quality featured study based on Qualitative Epistemology (GONZÁLEZ REY, 2005), and the analysis were substantiated from the meaning of the subjective sense (GONZÁLEZ REY, 2003, 2005). The objective of this article is to analyze the treasury server subjective senses in the light of the participation at work. The theoretical reference is the subjectivity theory in González Rey's $(2003,2005)$ historical-cultural perspective, which proposes a subjectivity conception from a man's historical-cultural comprehension, a theory that breaks with the dichotomy between social and individual. It was associated national and international studies about participation at work, such as O'Donoghue, Stanton and Bartram (20II), Zani and Spinelli (20I0), Neves and Castro (2010); Palgi (2006), Cox, Zagelmeyer and Marchington (2006), Demo (I988), Coutinho (2006) and Leal Filho (2009). The adopted concept of participation is associated to the ways and means by which workers and directors of an organization can influence their destinies (MOTTA, I999).The subjects researched are seven tax auditors from the Secretaria de Estado da Fazenda do Espírito Santo (Sefaz). The data collection took place in four empirical moments between July 2009 and February 2010. The interpretations exposed relevant subjective senses in each of the subjects researched in the light of the participation at work, and also in the light of: ideological points of view; family core and self-esteem; the new and changes; formality and family. The outcomes made 
possible the identification of remarkable elements of the social subjectivity prevailing in the institution, highlighting: control based culture; miscomprehension between friendship and professional relations; lack of participation space. In the end, measures were suggested in order to better the institution-worker relation and the participation of workers at work, gaps and limitations in the study, and future questions for a future study were also approached.

\section{KEYWORDS}

Participation at work; Subjectivity; Subjective senses; Tax auditor; Public Administration.

\section{LA VIDA EN LA HACIENDA: SENTIDOS SUBJETIVOS \\ DEL SERVIDOR HACENDERO FRENTE A LA \\ PARTICIPACIÓN EN EL TRABAJO}

\section{RESUMEN}

El problema de investigación tuvo origen en inquietudes de los investigadores sobre la diversidad y la complejidad de los problemas relacionados a la participación en el trabajo, ni siempre posibles de ser explicados a partir de elementos objetivos. Esa comprensión norteo la opción por el estudio de naturaleza cualitativa basada en la epistemología cualitativa (GONZÁLEZ REY, 2005) y los análisis fueron fundamentados a partir de la acepción del sentido subjetivo (GONZÁLEZ REY, 2003, 2005). El objetivo de este artículo es analizar los sentidos subjetivos del servidor de hacienda frente a la participación en el trabajo. El referencial teórico es la teoría de la subjetividad en la perspectiva histórico-cultural de González Rey (2003, 2005), que propone una concepción de subjetividad a partir de una comprensión histórico-cultural del hombre. Están asociados también estudios nacionales e internacionales sobre la participación em el trabajo, como O’Donoghue, Stanton y Bartram (20II), Zani y Spinelli (20I0), Neves y Castro (2010), Palgi (2006), Cox, Zagelmeyer y Marchington (2006), Demo (i988), Coutinho (2006) y Leal Filho (2009). El concepto de participación adoptado está asociado a las formas y a los medios por los cuales los trabajadores y dirigentes de una organización pueden influenciar sus destinos (MOTTA, I999). Los sujetos investigados son siete auditores fiscales de la Secretaria de Estado de la Hacienda de Espírito Santo (Sefaz). El levantamiento de los datos se dio entre julio de 2009 y febrero de 2010 . Interpretaciones evidenciaron sentidos subje- 
tivos relevantes en cada uno de los sujetos investigados, asociados: a la visión ideológica; al núcleo familiar; a la autoestima; a lo nuevo y al cambio; a la formalidad y a la familia. Los resultados posibilitaron aún la identificación de elementos resaltantes de la subjetividad social prevaleciente en la institución, con destaque para: cultura basada en el control; mezcla entre relaciones de amistad y relaciones profesionales; y carencia de espacios de participación. Al final, fueron sugeridas medidas en el sentido de mejorar la relación servidor-institución y la participación en el trabajo, abordados limitaciones del estudio y señaladas las interrogantes que pueden ser objetivo de estudio en el futuro.

\section{PALABRAS CLAVE}

Participación en el trabajo; Subjetividad; Sentidos subjetivos; Auditor fiscal; Administración Pública.

\section{REFERÊNCIAS}

ARENDT, H. O que é política? 2. ed. Rio de Janeiro: Bertrand Brasil, I999.

CASTRO, P. P.; PACHECO, L.; PATRUS-PENA, R. Relacionando variáveis da gestão de pessoas nas organizações: gestão participativa forte enfraquece as relações com os sindicatos? In: ENCONTRO NACIONAL DOS PROGRAMAS DE PÓS-GRADUAÇÃO EM ADMINISTRAÇÃO, 33., 2009, São Paulo. Anais... São Paulo: Anpad, 2009.

COUTINHO, M. C. Participação no trabalho. São Paulo: Casa do Psicólogo, 2006.

COX, A.; ZAGELMEYER, S.; MARCHINGTON, M. Embedding employee involvement and participation at work. Human Resource Management Journal, v. I6, n. 3, p. 250-267, 2006.

DEMO, P. Participação é conquista. São Paulo: Cortez, Autores Associados, I988.

DI PIETRO, M. S. Z. Direito administrativo. r6. ed. São Paulo: Atlas, 2003.

GHORPADE, J.; LACKRITZ, J.; SINGH, G. Views of employee participation, higher order needs, altruism, pride in craftsmanship, and collectivism: implications for organizational practice and public policy. Journal of Applied Social Psychology, v. 36, n. Io, p. 2474-249I, 2006.

GONZÁLEZ REY, F. L. La Investigación cualitativa en psicología: rumbos y desafíos. São Paulo: Educ, I999.

Sujeito e subjetividade. São Paulo: Pioneira Thomson Learning, 2003.

. Pesquisa qualitativa e subjetividade. São Paulo: Pioneira Thomson Learning, 2005.

KLIKSBERG, B. Seis teses não-convencionais sobre participação. Revista de Administração Pública, Rio de Janeiro, v. 33, n. 3, p. 7-37, maio/jun. I999.

LEAL FILHO, J. G. Gestão estratégica participativa. 2. ed. Curitiba: Juruá, 2009.

MCCREA, P. B.; FERGUSON, M. Reducing work-to-life interference in the public service: the importance of participative management as mediated by other work attributes. Journal of Sociology, v. 47, n. 3, p. 3I3-332, $201 \mathrm{I}$. 
MCLAGAN, P. A. A nova era da participação: o desafio de emocionar e envolver pessoas. Rio de Janeiro: Campus, 2000.

MELLO, C. A. B. de. Curso de direito administrativo. r2. ed. São Paulo: Malheiros, 2000.

MENDONÇA, L. C. de. Participação na organização: uma introdução aos seus fundamentos, conceitos e formas. São Paulo: Atlas, I987.

MOTTA, P. R. Gestão contemporânea: a ciência e a arte de ser dirigente. Rio de Janeiro: Record, I999.

NEVES, F. de S.; CASTRO, J. M. de. A participação e o envolvimento dos servidores como fatores críticos para a implementação de um processo de mudança organizacional: um estudo de caso no governo do estado de minas gerais. In: ENCONTRO NACIONAL DOS PROGRAMAS DE PÓSGRADUAÇÃO EM ADMINISTRAÇÃO, 34., 20Io, Rio de Janeiro. Anais... Rio de Janeiro: Anpad, 2010 .

O'DONOGHUE, P.; STANTON, P.; BARTRAM, T. Employee participation in the healthcare industry: the experience of three case studies. Asia Pacific Journal of Human Resources, v. 49, n. 2, p. I93-2I2, June 20II.

PAES DE PAULA, A. P.; PALASSI, M. P. Subjetividade e simbolismo nos estudos organizacionais: um enfoque histórico-cultural. In: CARRIERI, A. P.; SARAIVA, L. A. S. (Org.). Simbolismo organizacional no Brasil. São Paulo: Atlas, 2007.

PALGI, M. Experiences of self-management and employee participation. International Review of Sociology, v. I6, n. I, p. 49-53, 2006.

PEREIRA, G. M.; OSBUM, H. G. Effects of participation in decision making on performance and employee attitudes: a quality circles meta-analysis. J. Bus. Psychol., v. 22, n. 2, p. I45-I53, 2007.

PRESTES-MOTTA, F. C. Participação e co-gestão. Novas formas de administração. São Paulo: Brasiliense, I982.

SEN, A. Democracy as a universal value. Journal of Democracy, v. Io, n. 3, p. 3-17, I999.

SILVA, Á. J. dos S.; REZENDE, L. G. Sindifiscal-ES: suas lutas e conquistas. Vitória: Sindifiscal, 2009 .

SILVEIRA, R. Z.; PALASSI, M. P. Produção científica sobre participação cidadã na Administração Pública: uma análise a partir dos artigos publicados nos principais eventos e revistas nacionais de Administração (I997-2008). In: COLÓQUIO INTERNACIONAL DE PODER, II., 2009, Salvador. Anais... Salvador: UFBA, 2009 .

ZANI, F. B.; SPINELLI, R. Q. Inovação na gestão pública: eficiência com participação? In: ENCONTRO NACIONAL DOS PROGRAMAS DE PÓS-GRADUAÇÃO EM ADMINISTRAÇÃO, 34., 20IO, Rio de Janeiro. Anais... Rio de Janeiro: Anpad, 20 oо. 